\title{
China's Belt and Road initiative: can Europe expect trade gains?
}

ALICIA GARCIA HERRERO AND JIANWEI XU

\section{ABSTRACT}

The Belt and Road initiative, recently embarked on by China, aims to improve cross-border infrastructure in order to reduce transportation costs across a massive geographical area between China and Europe. We estimate how much trade might be created among Belt and Road countries as a consequence of the reduction in transportation costs (both railway and maritime) and find that European Union countries, especially landlocked countries, should benefit considerably. This is also true for eastern Europe and Central Asia and, to a lesser extent, south-east Asia. In contrast, if China were to seek to establish a free trade area within the Belt and Road region, EU member states would benefit less, while Asia would benefit more. Xi Jinping's current vision for the Belt and Road, centred on improving transport infrastructure, is very good news for Europe as far as trade creation is concerned.

Key words: China, Belt \& Road initiative, infrastructure, international economic system

JEL codes: F02, 019, 053 


\section{Introduction}

The Belt and Road project is undoubtedly the most important international project that China has embarked on in the last few decades. It aims to stimulate economic development over a vast area covering sub-regions in Asia, Europe and Africa. Although there has been no official announcement about what countries are covered by the Belt and Road initiative, some official sources point to the involvement of at least 63 countries, including 18 European countries ${ }^{1}$. Particularly relevant for Europe is that the Road ends where the European Union (EU) starts. Most importantly, this massive bloc between the EU and China accounts for 64 percent of the world's population and 30 percent of global GDP.

One of the Belt and Road's key objectives is to ease bottlenecks for cross-border trade, in particular through transport infrastructure. This should reduce the cost of transportation, thus stimulating trade between China and these countries. The same effect should be expected for the other end of the road the EU - because cheaper transportation should also foster its trade with other Belt and Road countries, as well as with China. This paper measures empirically whether the reduction in transportation costs - shipping or railway costs - will have a positive impact on trade flows for Belt and Road countries and, most importantly, for EU countries.

In addition to estimating the size of the trade gains stemming from a reduction in transportation costs, we explore the possibility that the Belt and Road may eventually go beyond its current objectives towards the creation of a free trade area. To that end, we establish a scenario in which China embarks on a free trade agreement (FTA) with the 63 countries of the Belt and Road initiative. This exercise is particularly relevant at the current juncture because the Trans-Pacific Partnership (TPP), a free trade agreement between a number of Pacific economies and the US, is about to be created ${ }^{2}$. China has so far been excluded from the TPP. In other words, we aim to identify empirically what kind of trade gains countries could expect from a reduction of transportation costs and to compare them with potential trade gains from reductions in tariffs stemming from a potential FTA. While our analysis estimates gains/losses for a large number of countries, our focus is EU member states. Our results indicate that the reduction in transportation costs from the Belt and Road initiative should benefit the vast majority of EU countries, especially landlocked countries. In comparison, if China reached a deal for the establishment of an FTA with the countries of the Belt and Road initiative, the benefits would be concentrated among Asian and non-western European countries. EU countries' trade, in turn, would be harmed although in a relatively limited way. The reason for this is substitution of EU trade with countries within the Belt and Road as their intra-regional trade tariffs are dismantled. In a nutshell, this paper points to the benefits for the EU of Xi Jinping's current vision for the Belt and Road initiative, which focuses on improving transport infrastructure rather than on a establishing a free trade area within the Belt and Road region.

\section{Trade as a key pillar of the Belt and Road initiative}

The Belt and Road's key pillars to improve regional and international connectivity are infrastructure upgrade and trade facilitation. There are two major projects: one focuses on land connectivity and the other on sea routes. More specifically, the Silk Road Economic Belt comprises six economic corridors

\footnotetext{
${ }^{1}$ Different sources vary in their definitions of Belt and Road countries. We choose a conservative definition of 63 countries, the number of countries invited by the Belt and Road Forum held by the General Administration of Customs of China in 2015. However, there are other sources indicating more extensive coverage. For example, the Industrialization of the Belt and Road Countries Report published by the China Academy of Social Science includes 65 countries.

${ }^{2}$ It should be noted that the 2016 US election campaign is raising doubts about whether TPP will finally be ratified by the US Congress. Both the Republican and Democrat candidates have expressed dissatisfaction with the deal.
} 
with a focus on transportation infrastructure and energy. Two of these corridors end in the EU and a third finishes in Europe, although not in the EU (Figure 1).

\section{Figure 1: Roadmap for the Belt and Road initiative}

The Belt and Road Initiative: Six Economic Corridors Spanning Asia, Europe and Africa

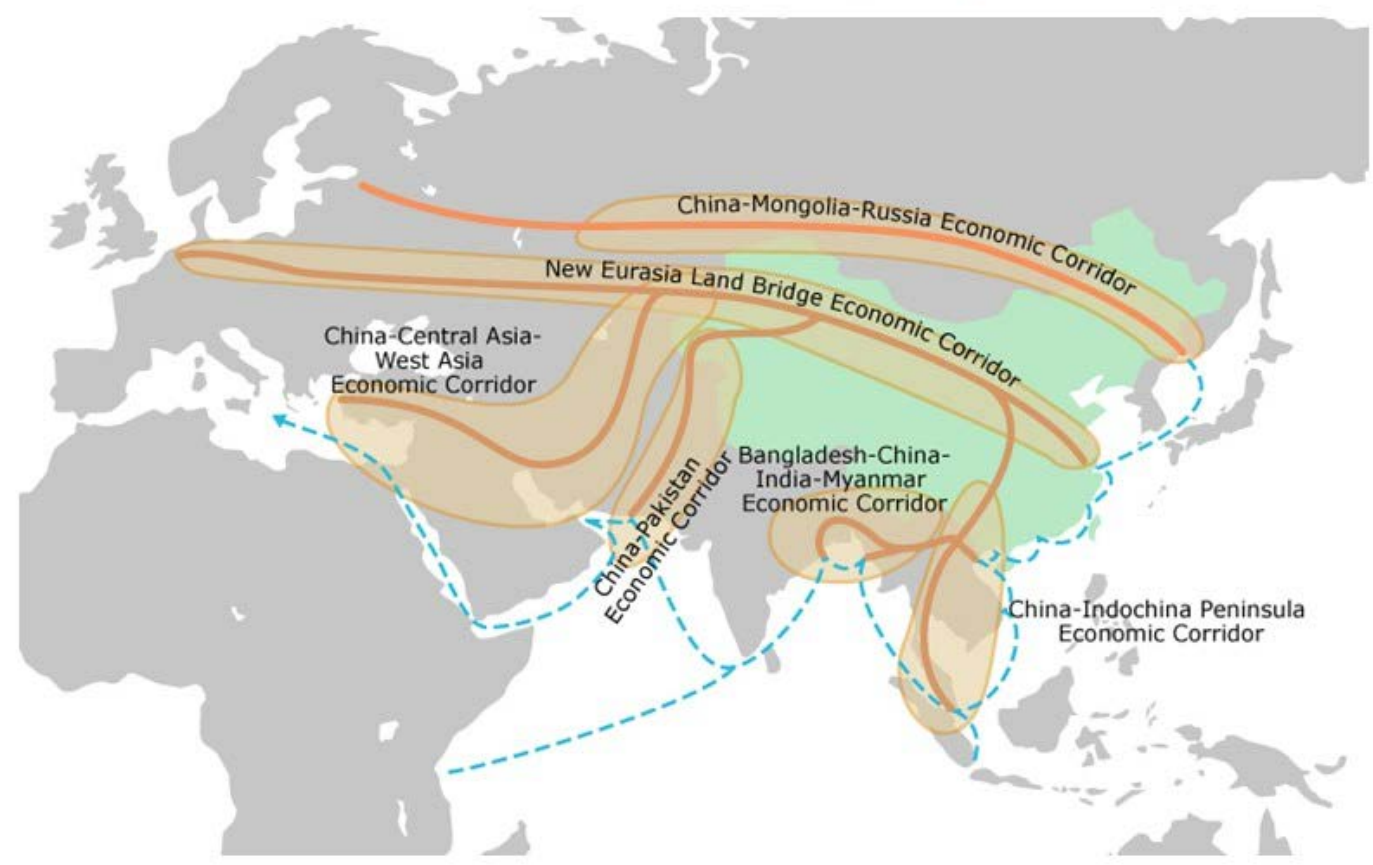

Source: HKTDC Research, http://china-trade-research.hktdc.com/business-news/article/One-Belt-One-Road/The-Belt-andRoad-Initiative/obor/en/1/1X000000/1X0A36B?.htm

There has been much speculation on the underlying reasons for China to engage in such a massive project (Garcia-Herrero, 2015). One of the main reasons put forward is China's massive overcapacity (Djankov et al, 2016). While some of the overcapacity sectors are not necessarily obvious export sectors, cement being the best example, some offer the potential for greater exports. The best case given its sensitivities in Europe ${ }^{3}$ - may be steel, in which China has rapidly been increasing its global market share (Figure 2). Overall, given the very negative impact of China's overcapacity on its economy - as clearly indicated by the strongly negative producer prices - the Belt and Road appears to be a huge opportunity for Chinese exporters, given the huge economic and population size of the Belt and Road area. Given that the EU is at the other end of the Belt and Road, the question is whether European exporters will also benefit from such initiative.

\footnotetext{
${ }^{3}$ The European Commission said in July 2016 that it will increase import tariffs on China's steel exports for anti-dumping reasons.
} 
Figure 2: China's steel production utilisation rate and global export market share [\%]

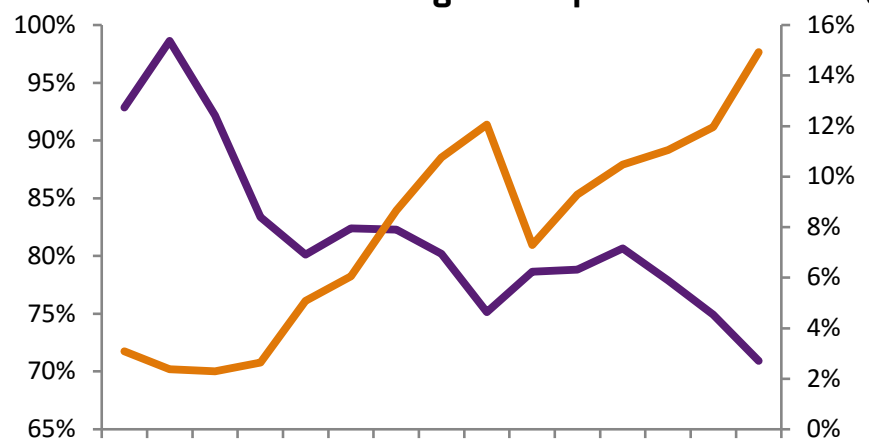

$\begin{array}{lllllllllllllll}14 & 13 & 12 & 11 & 10 & 09 & 08 & 07 & 06 & 05 & 04 & 03 & 02 & 01 & 00\end{array}$

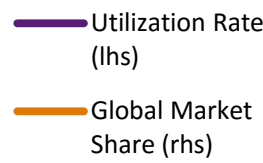

Source: Bruegel based on China Iron and Steel Association, UNCTAD, Bloomberg, Natixis.

A very important point to take into account when assessing the impact of transportation costs on trade is how much a transportation mode whether maritime, road or railway, is used relative to others. In Figures 3 and 4, we find that China's trade transportation is dominated by the maritime mode while the EU is dominated by land transportation 4 .

\section{Figure 3: Share of Chinese trade by} transportation mode

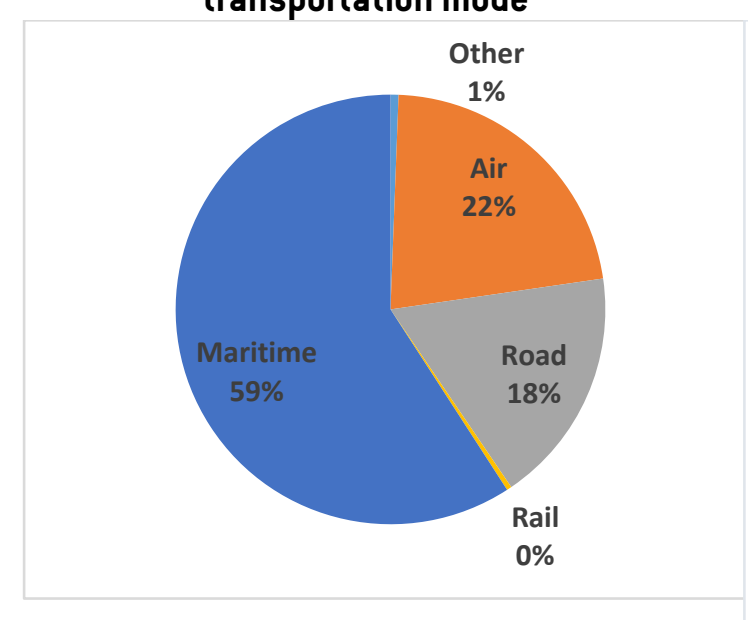

Source: China Customs data.

\section{Figure 4: Share of EU's trade} by transportation mode

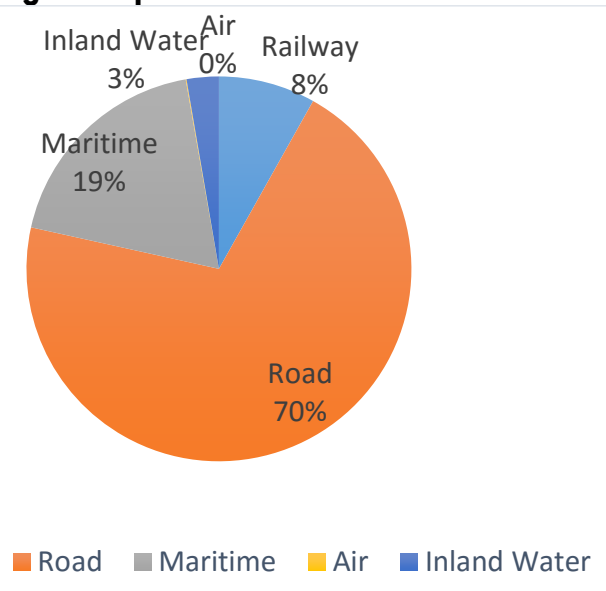

Source: Eurostat transport database, http://ec.europa.eu/eurostat/web/transport/data/database. Note: We calculate the freight share of goods for each transportation mode.

\footnotetext{
${ }^{4}$ Note that the share is calculated by trade value for China but by freight weight for the EU. Calculating share by freight weight might to some extent underestimate the share of air transportation because higher weight goods are less likely to be transported by air. However, even so the comparison between maritime and land transportation might not be totally warranted as land transportation is still dominant for EU-China trade.
} 


\section{Our approach to measuring the impact of the Belt and Road Initiative on trade}

While the Belt and Road is a massive project with a number of implications, we focus on one of the key trade issues, namely the expected improvement in transport infrastructure. We ask whether and by how much the improvement will increase trade, and for which countries. We use a gravity model to assess empirically what the impact of a reduction in transportation costs might be on bilateral trade for all of the countries for which we can find relevant transport data.

\section{Methodology}

We choose the model specification proposed by Baier and Bergstrand (2009) because it has a rigorous theoretical background and can quantify not only the effect of a reduction in transportation time and/or cost on bilateral trade, but also the spillover effect (also called the 'multilateral resistance effect') on third countries (Anderson and Wincoop, 2003). The benefit of this method is that it takes into account the reaction of third countries to changes in the determinants of bilateral trade between two countries, while still avoiding the complexity of a more structural specification. The estimation equation is specified as follows:

$$
\begin{aligned}
\operatorname{In}\left(\text { Trade }_{i j}+1\right) & =b_{0}+b_{1} \ln \left(Y_{i}\right)+b_{2} \ln \left(X_{j}\right)+b_{3} \text { Tariff }^{\prime} \\
& +b_{4,1} \ln \left(\text { RailC }_{i j}{ }_{i j}\right)+b_{4,2} i \ln \left(\text { AirC }_{i j}{ }_{i j}\right) \\
& +b_{4,3} \ln \left(\text { Ocean }_{C_{i j}}{ }_{i j}\right)+b_{5} \text { controls }_{i j}+e_{i j}
\end{aligned}
$$

Where Trade $_{i j}$, refers to export values from country $i$ to country $j$, Tariff ${ }_{i j}$, Rail $C_{i j}^{\prime}$, Air $C_{i j}^{\prime}$, Ocean $C_{i j}^{\prime}$ are bilateral tariffs, railway transportation costs, air costs and maritime costs that have been adjusted for the multilateral resistance factors ${ }^{5}$. Furthermore, $Y_{i}$ is the GDP of the exporting county and $X_{i}$ is the GDP of the importing country. Other control variables are contiguity between two countries (ie those with shared borders], common currency, common language and post-colonial relationships ${ }^{6}$.

\section{Data description}

One of our key challenges was how to measure transportation costs between two countries and, even more so, which assumptions to make in terms of the future reduction of such transportation costs because of the improvement in infrastructure resulting from the Belt and Road initiative.

For the measurement of transportation costs, we focus on sea, road, railway and air distance between any two capitals. We use several different databases, namely SEARATES for sea transportation and ROME2RIO and Google Maps for railways and roads. Regarding our objective variable, i.e. bilateral trade, we use databases from UN Comtrade (1999) and CEPII for our bilateral trade pairs. Based on data availability, we ended up with a sample of 16,748 country-pairs for 137 countries in the year 2013?, including all $28 \mathrm{EU}$ countries, 56 Belt and Road initiative countries, and a number of major economies outside Eurasia. Appendix I provides more detailed analysis of the sample coverage and summary statistical analysis.

\footnotetext{
${ }^{5}$ See equation (A4) in the appendix.

${ }^{6} \mathrm{~A}$ discerning reader might find that we do not add multilateral resistance terms for our control variables. We do this only to simplify our analysis. We believe this assumption is plausible. As we show (see also Head and Mayer, 2014), multilateral resistance terms only generate marginal impact compared to the main direct effect, and the coefficients are stable with or without control variables. As such, ignoring these effects is expected to generate only very minor impacts on our main coefficients.

${ }^{7}$ As a standard technique in the gravity model literature, we also include the country pairs for internal trade, ie a country's trade with itself, such as sales from China to China.
} 


\section{How sensitive is trade to transportation costs}

Our results show that a reduction in transportation costs has a statistically significant and positive impact on international trade. We report the best of our results (details of four different estimations can be found in the Appendices), namely those that take into account third-country effects (i.e., including the multilateral resistance term in Equation 1) as well as all control variables. We find that a 10 percent reduction in railway, air and maritime costs increases trade by 2 percent, 5.5 percent and 1.1 percent respectively. In other words, transportation costs are found to be statistically and economically significant in fostering international trade.

Next, we move to comparing the impact of a reduction in transportation costs to a reduction in tariffs for international trade. This is a very relevant since we could think of the Belt and Road initiative as a sort of substitute free trade agreement as long as reductions in transportation costs are as effective in fostering trade as is dismantling tariffs. It is an important issue for China which has long feared being excluded from the largest - and most relevant - trade deal in the Pacific, ie the TPP. The reduction of transportation costs in an area as vast as the Belt and Road area should help reduce China's worries about TPP as long the infrastructure that is being built does create new trade opportunities.

Our empirical paper confirms this a priori. More specifically, a reduction in air and railway costs increases by trade more than a reduction in ad valorem tariffs (larger marginal impact). More specifically, a 10 percent reduction in transportation costs fosters trade by 1.3 percent while a reduction in tariffs has a much smaller positive effect.

\section{Scenario I: Simulating the impact on trade of a reduction in transportation costs}

The fact that the Belt and Road initiative is still in its early phases obliges us to use a simulation exercise to understand what its impact might be on international trade. As in any simulation exercise, there is uncertainty around the hypothesis behind the simulation. In our case, in particular, it is clearly difficult to estimate how much transportation costs will be reduced as a result of the improvement in infrastructure.

There is obviously no comprehensive information that we can gather because the improvements in infrastructure - or construction of new infrastructure - do not yet exist or are still under construction. However, information on the few finalised projects can give a hint of the potential cost reduction in transportation. In the case of railway, the best example is the Yuxinou Railway (from Chongqing to Duisberg) because it is already functioning and data on the reduction in transportation time is available. More specifically, Chongqing's mayor declared in 2015 that railway transportation costs on that route had been slashed by 50 percent. This is in line with the reduction in transportation time that has been achieved by introducing this new railway line: from 17-18 days to $12-13$ days according to the Yuxinou official website and Chinese national official media ${ }^{8}$. In the case of maritime transportation, the cost savings stem from efficiency improvements in ports, many of which have not even been finalised. However, some examples of improvements in efficiency already exist, in particular for the Qingdao port. After some improvements in the functioning of the port, Qingdao customs reported that transportation costs out of and into the port would be reduce by about 5 percent ${ }^{9}$. Smaller reductions

\footnotetext{
${ }^{8}$ PEOPLE.CN. This information can be found at http://politics.people.com.cn/n/2014/1029/c70731-25927853.html,

http://www.yuxinoulogistics.com/detailed.asp?sid=229.

${ }^{9}$ There are no official statistics on how Belt and Road can facilitate maritime trade, but there is some evidence of improvements in clearance efficiency: http://qingdao.customs.gov.cn/publish/portal105/tab63061/info785626.htm, and http://www.gov.cn/xinwen/2015-05/05/content 2856850.htm.
} 
in maritime costs compared to railway costs seems logical if one considers that ports are already very efficient in a number of Asian countries, so only more limited gains might be possible even if the infrastructure improves.

In this exercise, we take this information and apply the reduction of transportation costs across the board within the Belt and Road area. It should be noted that we do not include the cost of such improvements in transport infrastructure because of lack of data. More specifically, we reduce railway transportation costs by 50 percent and sea transportation costs by 5 percent, for the geographical area under the Belt and Road project.

Panel A of Figure 5 reports the simulated top ten winners from the Belt and Road initiative, whose gains in trade range from 8 percent to 10 percent once transportation costs are reduced as previously stated. All of the top winners are located in Europe, with eight of them within the EU. Panel B of Figure 5 shows the top ten losers, all of which are outside Europe and Asia. This looks like a very logical finding because the rest of the world will not benefit as much from the improvement in infrastructure. In any event, trade losses are rather minimal so the impact is more about not gaining trade rather than losing trade. In fact, the negative impact on trade is less than 0.2 percent even for the biggest losers. Asian countries are not found to be among either the biggest winners or losers. This is probably explained by the fact that the estimated reduction in maritime transportation costs is quite moderate.

\section{Figure 5: Who wins and who loses in the transportation scenario}

Panel A: Top 10 winners in trade

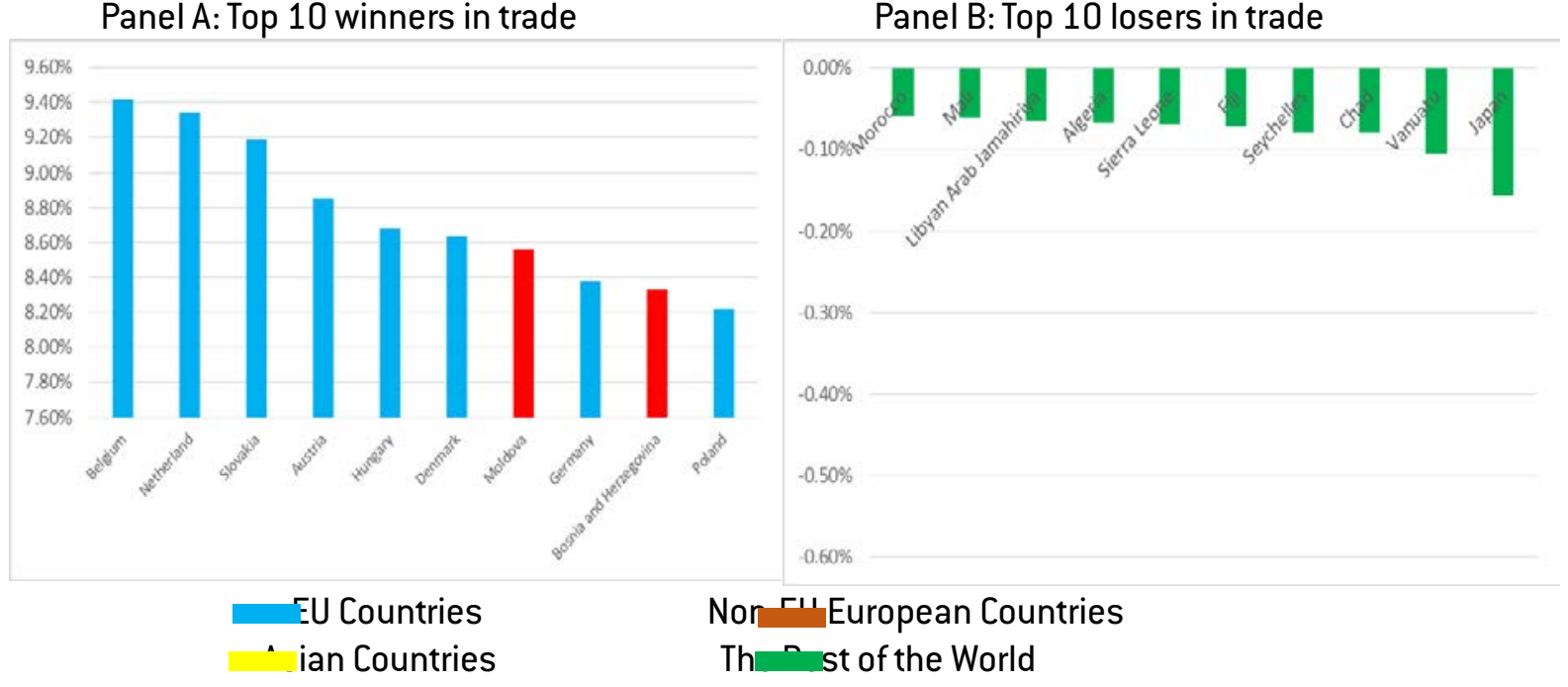

Source: Bruegel.

Figure 6 shows the simulation results by region. The impact on trade by region is shown in panel $A$. The EU is the biggest winner from the Belt and Road initiative, with trade rising by more than 6 percent. Trade in the Asian region is also positively affected by the reduction in transportation costs, but only by half as much as the EU, with trade increasing by 3 percent. Conversely, the rest of the world suffers from a very slight reduction in trade ( 0.04 percent). The findings by region basically confirm our analysis at the country level. As a whole, our results point to the Silk Road being a win-win in terms of trade creation because the gains from EU and Asia clearly outweigh the loss felt by the rest of the world. 
Figure 6: Regional trade impacts of the reduction in transportation costs

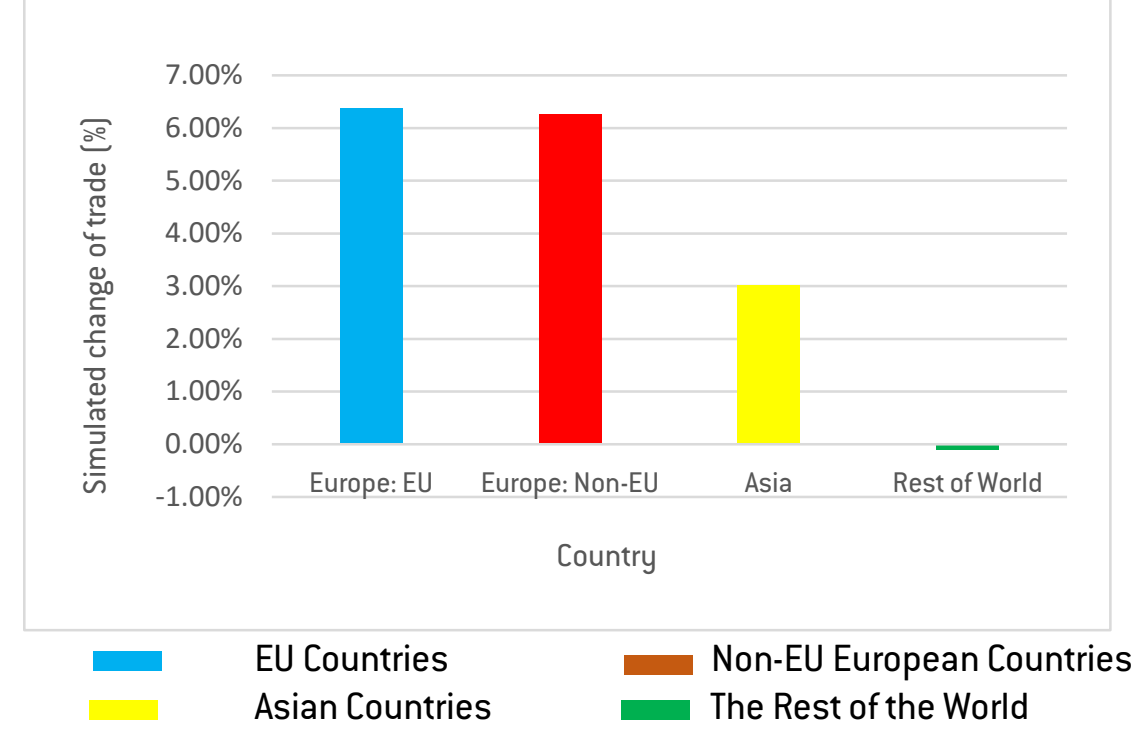

Source: Bruegel.

\section{Scenario II: Simulating trade gains from establishing a free trade agreement within the Belt and Road area}

We now compare the previously estimated trade gains from Xi Jinping's current vision of the Belt and Road initiative, which is centred on the reduction of transportation costs by upgrading infrastructure, to those stemming from dismantling trade tariffs thanks to a free trade agreement among Belt and Road countries and China. Like the previous analysis, because of the lack of data, we do not include the costs of negotiating and implement a free trade agreement. More specifically, we simulate the introduction of a free trade agreement within the Belt and Road area by cutting tariffs to zero and keeping transportation costs unchanged.

Figure 7 shows the five biggest winners from the establishment of a free trade agreement within the Belt and Road area, and compares their trade gains with those obtained from reduced transportation costs. The biggest winners are Middle Eastern and central and east Asian countries, with trade increases of more than 15 percent. This compares favourably with the trade gains of 3 percent stemming from a reduction in transportation costs that were estimated for this group of economies. EU countries, whose trade gains were the largest under the reduced transportation cost scenario, would now experience weak losses. The result is intuitive, because the EU countries would be outside the Belt and Road free trade agreement, so EU trade would be expected to be substituted to some extent by enhanced trade within the Belt and Road region. This is true even for EU countries formally included in the Belt and Road initiative, such as Hungary and Poland. This is because EU members cannot strike separate trade agreements with China, so they could not take part in a potential Belt and Road free trade agreement (Table 1). 
Figure 7: Comparison of transport cost reductions with a free trade agreement

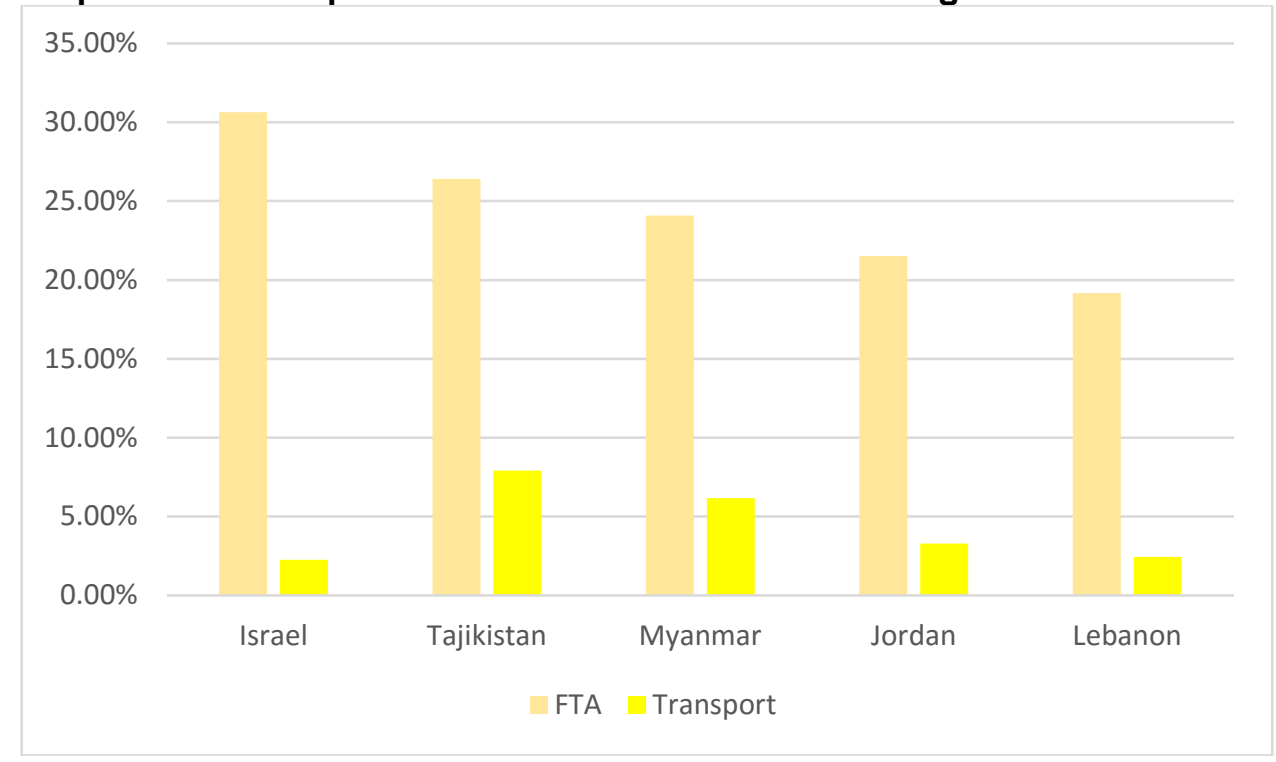

Source: Bruegel.

Figure 8 further summarises the regional impact on trade of a Belt and Road free trade agreement. The $\mathrm{EU}$, which was previously the biggest winner from the reduction in transportation costs, now suffers slightly from the Belt and Road free trade agreement. The Asian region becomes the biggest winner, followed by non-EU European countries, since they can also benefit from the elimination of trade tariffs. The impact of the regional free trade agreement on the rest of the world is positive, but much smaller than for the Asia and non-EU Europe regions.

Figure 8: Impact of a free trade agreement on trade by region

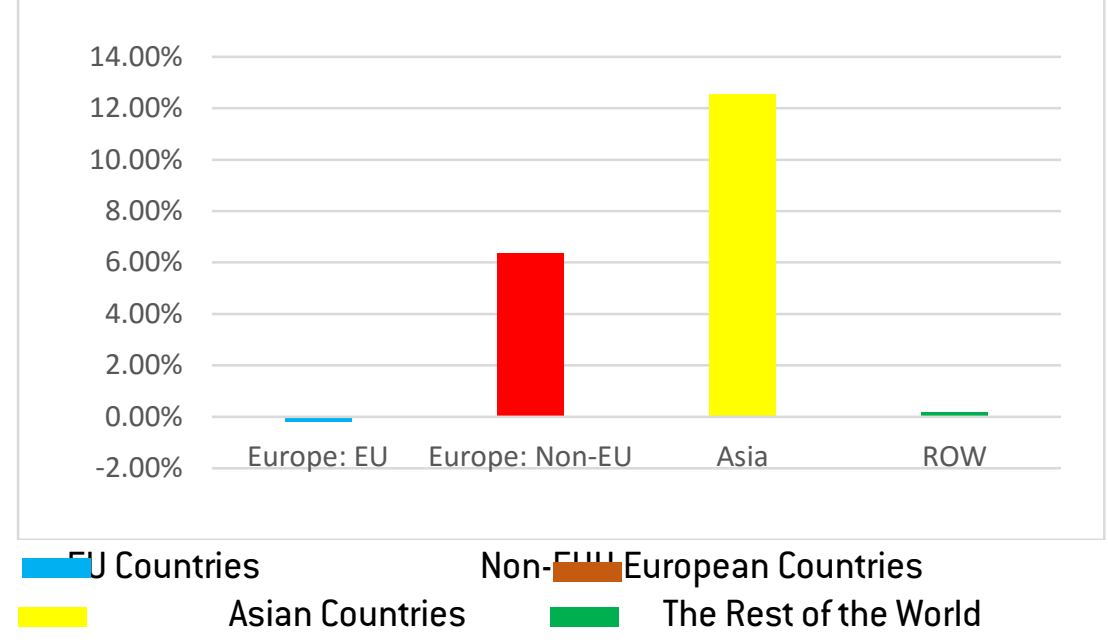

Source: Bruegel. 
Table 1: Estimated trade gains for EU countries under scenarios I, II and III

\begin{tabular}{|c|c|c|c|}
\hline Countries & $\begin{array}{l}\text { Simulated results for the } \\
\text { creation of an FTA within } \\
\text { the Belt and Road }(\%)\end{array}$ & $\begin{array}{l}\text { Simulated results for } \\
\text { reduction in Transportation } \\
\text { costs }(\%)\end{array}$ & $\begin{array}{l}\text { Simulated results for both creation } \\
\text { of an FTA and reduction in } \\
\text { transportation cost }(\%)\end{array}$ \\
\hline Belgium & $-0.02 \%$ & $9.42 \%$ & $9.40 \%$ \\
\hline Bulgaria & $-0.01 \%$ & $2.49 \%$ & $2.48 \%$ \\
\hline Croatia & $-0.01 \%$ & $3.96 \%$ & $3.95 \%$ \\
\hline Denmark & $-0.02 \%$ & $8.63 \%$ & $8.61 \%$ \\
\hline Estonia & $-0.01 \%$ & $3.33 \%$ & $3.32 \%$ \\
\hline Finland & $-0.05 \%$ & $6.14 \%$ & $6.10 \%$ \\
\hline France & $-0.02 \%$ & $7.64 \%$ & $7.62 \%$ \\
\hline Germany & $-0.02 \%$ & $8.37 \%$ & $8.35 \%$ \\
\hline Greece & $-0.04 \%$ & $5.30 \%$ & $5.26 \%$ \\
\hline Lithuania & $-0.04 \%$ & $6.81 \%$ & $6.77 \%$ \\
\hline Luxembourg & $-0.01 \%$ & $2.68 \%$ & $2.68 \%$ \\
\hline Malta & $-0.02 \%$ & $2.17 \%$ & $2.15 \%$ \\
\hline Netherland & $-0.02 \%$ & $9.35 \%$ & $9.33 \%$ \\
\hline Poland & $-0.03 \%$ & $8.22 \%$ & $8.19 \%$ \\
\hline Portugal & $-0.02 \%$ & $5.29 \%$ & $5.27 \%$ \\
\hline Romania & $-0.01 \%$ & $2.62 \%$ & $2.61 \%$ \\
\hline Slovakia & $-0.02 \%$ & $9.18 \%$ & $9.16 \%$ \\
\hline Slovenia & $-0.02 \%$ & $7.89 \%$ & $7.87 \%$ \\
\hline Spain & $-0.02 \%$ & $5.55 \%$ & $5.53 \%$ \\
\hline Sweden & $-0.03 \%$ & $1.12 \%$ & $1.09 \%$ \\
\hline
\end{tabular}

\section{Scenario III: Simulating trade gains from both transportation improvement and free trade}

Lastly, we consider a combined package including both transportation improvement and establishment of a Belt and Road free trade agreement. In this scenario, the effect is the total of scenarios I and II. Figure 9 offers an overview of the simulation results for some major economies.

Asian countries, such as Thailand and Vietnam, now become the biggest winners because they benefit from both the reduction in transportation costs and the elimination of trade tariffs. The EU also benefits quite significantly, but less than Asia. This is especially the case for some landlocked countries, such as Slovenia and Hungary, with trade gains of 8-9 percent, though these are still far below those experienced by Thailand and Vietnam. Among the developed countries, Germany also benefits slightly more than France, Spain and the UK (Table 1). This is actually very intuitive because the EU countries benefit from the transportation cost reduction but not the free trade arrangement. As the trade effect induced by transportation-cost reduction in the third scenario is smaller than that of the first tariff reduction scenario, it is in the EU countries' interest to cooperate with China on transportation projects connecting the two areas.

As is in the previous two scenarios, there are always some slight losses for countries far from the Belt and Road project, the biggest being Japan ( -0.6 percent) while the impact on the US and Canada is very close to zero. 
Figure 9: Simulation for the combined effect of transportation-cost reduction and establishment of the free trade agreement

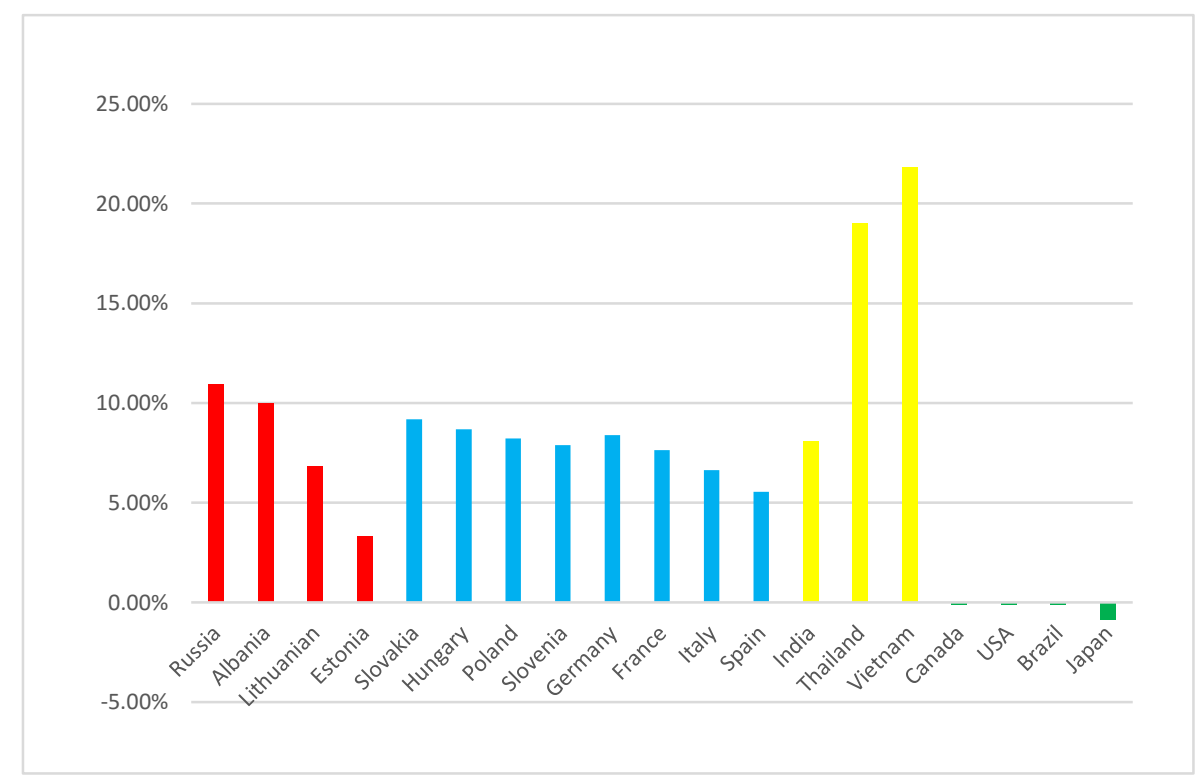

\section{Conclusions}

Our simulations show that EU countries would be clear winners in three different scenarios illustrating how Xi Jinping's Belt and Road initiative could develop and impact EU and global trade.

This is especially the case for Xi Jinping's current vision for the Belt and Road, which is centred on the construction or improvement of transport infrastructure to reduce rail and maritime transportation costs. A free trade agreement between the Belt and Road countries and China would have a less positive impact. This is also true for eastern Europe and Central Asia and, to a lesser extent, south-east Asia. In contrast, if China were to embark on creation of a free trade area within the Belt and Road region, EU member states would no longer benefit, while Asia would.

Our results, even if not fully comprehensive because of the lack of data, should be very encouraging for the EU. This would be even more the case if we could include the cost of improving such transport infrastructure, because the financing should mainly come from China - together with the countries within the Belt and Road, but not from the EU.

In a nutshell, Xi Jinping's current vision for the Belt and Road, centred on improving transport infrastructure, is very good news for Europe as far as trade creation is concerned. Confronted with such good news, it is quite striking that the discussion on the impact of the Belt and Road on Europe is still very embryonic. It goes without saying that more research is needed on the topic as trade is only one of the many ways through which the Belt and Road initiative might affect Europe. Financial channels, such as foreign direct investment and portfolio flows, are also very relevant and deserving of analysis. 


\section{Appendix 1: Data sources and statistics}

We use data from various sources. The bilateral data in 2014 was obtained from the UN Comtrade Dataset, which provides bilateral trade value for exports and imports denoted in the US dollars from every country pair. Because the differences in measures usually lead to similar gravity estimation results, we only use country exports to measure bilateral trade value. To analyse the extensive margin of trade, the missing country pairs are replaced by zero trade flows.

To measure transportation costs we rely on the traditional index of 'distance'. We calculate ocean, road, railway and air distances for the corresponding cost of each transportation mode between any two capitals as a proxy for countries.

(1) Ocean distance is obtained from www.searates.com, which reports regular shipping distance between any two cities, including both the within-country transportation distance and acrosscountries transportation distance.

(2) To the best of our knowledge, railway distances are not readily available in any existing database. We first calculate the distances from Rome2Rio ${ }^{10}$. We insert the name of each capital (of the country) as the starting and destination in Rome2Rio respectively, then choose railway transportation, and finally obtain the distance of the railway route. Note that direct trains are not always available for country pairs, and some routes may require transfer via bus or metro, so we connect these countries if railway comprises a major way of transportation. Trans-continental routes from Asia to Europe, which are crucial to our analysis, are not available in Rome2Rio. To fill in the trans-continental routes we rely on United Nations (1999), which gives railway distances for 16 major cities in Europe and Asia, and we connect these lines to the other city of Europe by adding distances of related cities from Rome2Rio.

(3) Air distance is proxied by the geographic distance between the two countries. To that end, we calculate the population-weighted distance between large cities in the two countries. The source is CEPII.

Merging these datasets finally leads to a sample of 16,748 bilateral trade observations covering 137 countries. These countries are reported in table A1.1.

Table A1.1: Countries covered in our sample

\begin{tabular}{|l|l|l|}
\hline European Union & $\begin{array}{l}\text { Belt and Road countries (excluding } \\
\text { European Union) }\end{array}$ & Rest of the world \\
\hline Austria, Belgium, & Albania, United Arab Emirates, & Algeria, Argentina, Australia, \\
Bulgaria, Croatia, & Armenia, Azerbaijan, Bosnia and & Bahamas, Bangladesh, Belize, \\
Cyprus, Czech & Herzegovina, Belarus, Brunei & Botswana, Brazil, Burundi, \\
Republic, Denmark, & Darussalam, Bhutan, China, Egypt, & Cameroon, Canada, Central African \\
Estonia, Finland, & Georgia, Croatia, Hungary, & Republic, Chad, Chile, Colombia, \\
France, Germany, & Indonesia, India, Iran, Iraq, Israel, & Dominica, Dominican Republic, \\
Greece, Hungary, & Jordan, Kazakhstan, Kyrgyzstan, & Ecuador, Ethiopia, Fiji, Gabon, \\
\hline
\end{tabular}

${ }^{10}$ Rome2Rio is a comprehensive multimodal transport search engine launched in April 2011: https://www.rome2rio.com. 


\begin{tabular}{|c|c|c|}
\hline $\begin{array}{l}\text { Ireland, Italy, Latvia, } \\
\text { Lithuania, } \\
\text { Luxembourg, Malta, } \\
\text { Netherlands, Poland, } \\
\text { Portugal, Romania, } \\
\text { Slovakia, Slovenia, } \\
\text { Spain, Sweden and } \\
\text { the United Kingdom. }\end{array}$ & $\begin{array}{l}\text { Cambodia, Kuwait, Lao, Lebanon, } \\
\text { Liberia, Sri Lanka, Lithuania, Latvia, } \\
\text { Moldova, Maldives, Macedonia, } \\
\text { Myanmar, Malaysia, Nepal, Norway, } \\
\text { Oman, Pakistan, Philippines, Qatar, } \\
\text { Russia, Saudi Arabia, Singapore, } \\
\text { Thailand, Philippines, } \\
\text { Turkmenistan, Turkey, Ukraine, } \\
\text { Uzbekistan. }\end{array}$ & $\begin{array}{l}\text { Ghana, Honduras, Iceland, Japan, } \\
\text { Kenyan, Libya, Madagascar, } \\
\text { Malawi, Mali, Mauritania, } \\
\text { Mauritius, Mexico, Morocco, } \\
\text { Mozambique, Namibia, Nicaragua, } \\
\text { Niger, Nigeria, Panama, Paraguay, } \\
\text { Peru, Republic of the Congo, } \\
\text { Senegal, Seychelles, Sierra } \\
\text { Leone, South Africa, Swaziland, } \\
\text { Switzerland, Tanzania, Togo, } \\
\text { Trinidad and Tobago, Tunisia, } \\
\text { Uganda, United States, Uruguay, } \\
\text { Vanuatu Zambia Zimbabwe. }\end{array}$ \\
\hline
\end{tabular}

A number of other control variables from various sources are also included in this dataset. The GDP (expressed in dollars) for exporting and importing countries come from the World Bank WDI datasets. The product-level bilateral ad valorem tariff data is extracted from the TRAINS/WITS and the MACMap databases, developed jointly by ITC (UNCTAD-WTO, Geneva) and CEPII (Paris), and is aggregated to country-level weighted by the trade value from the last year. Other control variables, including contiguity, common currency, common legal origin, and colonial relationship, are obtained from the CEPII GRAVITY dataset.

Table A1.2 reports the summary statistics of the trade and transportation variables. Our sample includes China's exports to 129 countries, with the average bilateral export value reaching $\$ 13.30$ billion, far above the world average level. The Eurasian area as a whole plays an important role in world trade, with average bilateral trade for every country pair reaching $\$ 1.49$ billion, twice as large as the world average level. However, despite the region's significant contribution to international trade, transportation costs seem to hamper trade growth. For example, maritime transport was used for nearly 60 percent of China's total exports in 2013, but the maritime distance to the other countries reaches $16,233.12 \mathrm{~km}$ for China, surpassing the world average level of $10,874.93 \mathrm{~km}$. On the other hand, the railway distance for China is $9,138.74 \mathrm{~km}$, much less than the maritime distance. Considering that railway speed is at least twice as fast as maritime speed, railway transportation could potentially have a great impact in terms of cutting transportation times for China. On the European side, though the maritime distance is more approachable than world average, it is still twice as the railway distance. Road and railway transport comprises the largest share within the EU region, but few road and rail networks stretch out to the Asian area. Approximately 57 percent of China's trade with the EU was transacted via the maritime mode, while road and rail only comprises 18 percent of transaction value.

Table A1.2: Export value, maritime distance and railway distance

\begin{tabular}{c|c|c|c|c|c}
\hline & Variables & All & $\begin{array}{c}\text { China's } \\
\text { exports }\end{array}$ & EU's exports & B\&R+EU \\
\hline \multirow{2}{*}{$\begin{array}{c}\text { Export } \\
\text { value }\end{array}$} & $\begin{array}{c}\text { Country pair } \\
\text { observations }\end{array}$ & 16748 & 129 & 3203 & 4983 \\
\cline { 2 - 6 } & Average (billions) & 0.77 & 13.30 & 1.49 & 1.32 \\
\hline \multirow{2}{*}{$\begin{array}{c}\text { Maritime } \\
\text { distance }\end{array}$} & $\begin{array}{c}\text { Country pair } \\
\text { observations }\end{array}$ & 16748 & 129 & 3203 & 4983 \\
\cline { 2 - 6 } & Average $(\mathrm{Km})$ & $\begin{array}{c}10874.9 \\
3\end{array}$ & 16233.12 & 9258.10 & 9098.57 \\
\hline
\end{tabular}




\begin{tabular}{c|c|c|c|c|c}
\multirow{2}{*}{$\begin{array}{c}\text { Railway } \\
\text { distance }\end{array}$} & $\begin{array}{c}\text { Country pair } \\
\text { observations }\end{array}$ & 1292 & 37 & 698 & 1200 \\
\cline { 2 - 6 } & Average $(\mathrm{Km})$ & 5554.09 & 9138.72 & 4345.09 & 5570.15 \\
\hline
\end{tabular}

To supplement these results, we also obtain maritime time and fee statistics from two online sources: Sea Rates (www.searates.com) and World Freight Rates (www.worldfreightrates.com). Consistent with previous results, China's average shipping time to its trading partners is about 610 hours, much longer than the world average level, 406 hours. In particular, China's average shipping time to European partners reaches 730 hours, which is around 20 percent more even than China's average shipping time. This is embarrassing because the regions are geographically close. Although we do not have all official statistics reporting the railway time from China to Europe, a recent official report in China notes that the Yuxinou Railway which runs from Chongqing to Duisburg, Germany, only takes about 288 hours ${ }^{11}$. The evidence is clear that switching to railway transport has great potential for saving transport time. On the other hand, China's average shipping cost with European countries is only $\$ 922$ for a 40 foot container, about half as much as China's average shipping cost. A report from DB Schenker (2012) shows that the price for railway transport is three times as much as for maritime transport. There is thus no doubt a trade-off between time and cost in terms of railway transportation. To foster international trade via railway, it is also imperative to slash railway transport costs through infrastructure construction.

Table A1.3 reports the summary statistics for the other trade cost variables. China's average bilateral ad valorem tariffs is around 5.7 percent, nearly the same as the world average level, but significantly higher than for the EU, which is nearly zero. For the other time-invariant trade cost variables, there is no country that shares the same currency or a colonial relationship with China. One of the apparent advantages for China is that it is a giant country with a number of geographically neighbouring countries. On the contrary, similar currency and legal systems are apparent advantages for European countries in international trade terms.

Table A1.3: Summary statistics for the trade cost variables

\begin{tabular}{c|c|c|c}
\hline Variables & $\begin{array}{c}\text { World } \\
\text { average }\end{array}$ & $\begin{array}{c}\text { China } \\
\text { bilateral }\end{array}$ & EU region \\
\hline Ad valorem tariff & 0.057 & 0.058 & 0.004 \\
\hline Contiguity & 0.023 & 0.100 & 0.104 \\
\hline Common currency & 0.041 & 0.000 & 1.000 \\
\hline Common legal system & 0.301 & 0.223 & 0.237 \\
\hline Colonial link & 0.010 & 0.000 & 0.027 \\
\hline
\end{tabular}

${ }^{11} \mathrm{http}: / /$ newscontent.cctv.com/NewJsp/news.jsp?fileld=328706. 
Appendix 2: Comparison of maritime distance with railway distance for selected country pairs

\begin{tabular}{|c|c|c|c|c|c|}
\hline Origin & Destination & $\begin{array}{c}\text { Maritime } \\
\text { distance(km) }\end{array}$ & $\begin{array}{c}\text { Maritime } \\
\text { time } \\
\text { [estimated } \\
\text { range) }\end{array}$ & $\begin{array}{c}\text { Railway } \\
\text { distance } \\
\text { km }\end{array}$ & $\begin{array}{c}\text { Railway time } \\
\text { [estimated } \\
\text { range })\end{array}$ \\
\hline China & Azerbaijan & 19303.22863 & $429-965$ & 10060.8 & $101-335$ \\
\hline China & Germany & 21428.68397 & $476-1071$ & 8990.264 & $90-300$ \\
\hline China & Spain & 18062.58842 & $401-903$ & 12143.6 & $121-405$ \\
\hline China & France & 20877.96782 & $464-1044$ & 10818.6 & $108-361$ \\
\hline China & Russia & 23284.73579 & $517-1164$ & 7622 & $76-254$ \\
\hline Germany & Belgium & 1010.874734 & $22-51$ & 772.4851 & $8-26$ \\
\hline Germany & France & 1203.931161 & $27-60$ & 1084.215 & $11-36$ \\
\hline Germany & Tajikistan & 14158.57099 & $315-708$ & 5524.714 & $55-184$ \\
\hline Germany & Turkey & 7010.317227 & $156-351$ & 2632.2 & $26-88$ \\
\hline Spain & Belgium & 3629.254821 & $81-181$ & 1991.8 & $20-66$ \\
\hline Spain & France & 3790.446315 & $84-190$ & 1713.4 & $17-57$ \\
\hline Spain & Italy & 1574.465602 & $35-79$ & 2268.4 & $23-76$ \\
\hline France & Belgium & 462.7335302 & $10-23$ & 306.2 & $3-10$ \\
\hline France & Italy & 4455.538257 & $99-223$ & 1432.3 & $14-48$ \\
\hline France & Russia & 3059.870329 & $68-153$ & 3196.6 & $32-107$ \\
\hline France & Tajikistan & 13607.6939 & $302-680$ & 9734.215 & $97-324$ \\
\hline Kazakhstan & Germany & 14119.96292 & $314-706$ & 8765 & $88-292$ \\
\hline Kazakhstan & Spain & 10759.46788 & $239-538$ & 11528.4 & $115-384$ \\
\hline Kazakhstan & France & 13569.10193 & $302-678$ & 9849.215 & $98-328$ \\
\hline Uzbekistan & Germany & 12644.52001 & $281-632$ & 6138.038 & $61-205$ \\
\hline Uzbekistan & France & 12093.64292 & $269-605$ & 8484.215 & $85-283$ \\
\hline Vietnam & Spain & 15373.02723 & $342-769$ & 14993.6 & $150-500$ \\
\hline Vietnam & Germany & 18738.83309 & $416-937$ & 11840.26 & $118-395$ \\
\hline
\end{tabular}

Note: Maritime and railway time are estimated based on our assumption of speed: Maritime: '20 $\mathrm{km} / \mathrm{hr}$ - 45 km/hr'; Railway : '30 km/hr - 100 km/hr'. 


\section{Appendix 3: Gravity model methodology}

The effect of the Belt and Road initiative is estimated using a conventional gravity model, which is standard in modern trade policy evaluation. The advantage of the model is that it provides an explicit form for various types of trade cost. It is thus easy to compare transportation cost and time with the other types of trade cost. Additionally, the model has a rigorous theoretical background and can analyse not only the bilateral effect of transportation time and cost change, but also their spillover effect on the other countries. The latter is usually termed as multilateral resistance (Anderson and Wincoop, 2003).

To estimate the model we specify the trade between any two countries as a function of their log GDPs, tariffs, log transportation time and cost between them, and other control variables.

$$
\ln \left(\text { Trade }_{i j}+1\right)=b_{0}+b_{1} \ln \left(Y_{i}\right)+b_{2} \ln \left(X_{j}\right)+b_{3} \text { Tariff }_{i j}+b_{4} \ln \left(T C_{i j}\right)+b_{5} \text { controls }_{i j}+e_{i j} \text { (A1) }
$$

where trade $e_{i j}$ is the bilateral trade between country $i$ and $j$. We plus trade value with one before taking logarithm to avoid the zero trade problem. $Y_{i}$ is the GDP of the exporting county, $X_{i}$ is the GDP of the importing country, Tariffs $s_{i j}, T C_{i j}$, represents the tariffs and transportation cost between country $i$ and $j$. To get a measure for trade cost we use distance as a proxy. The control variables include: contiguity, common currency, common language, and post-colonial relationship. We plus trade with one to deal with the zero trade flow problem.

In this paper, we consider three types of transportation mode in international trade: ocean, airplane and railway. Although road is also a very important type of transportation mode, we do not include it in the paper for two reasons. First, pure road transport is only relevant for short-distance trade, and in most cases, road transport complements railway transport to facilitate international trade.

Second, road driving distances between countries are very similar to railway distance, thus putting them together usually leads to serious multicollinearity problems. Thus, we write $T C_{i j}$ in the following form,

$$
\ln \left(T C_{i j}\right)=i a_{1} \mid \ln \left(\text { Rail }_{i j}\right)+a_{2} \ln \left(\text { AirC }_{i j}\right)+a_{3} \ln \left(\text { OceanC }_{i j}\right) \text { (A2) }
$$

where $\alpha_{1}, \alpha_{2}, \alpha_{3}$ represent the differential impact of each transportation mode on total transportation cost. Note that not all $\alpha$ s is necessarily strictly positive than zero. For countries with only one or two transportation mode applied, one or two as can be set as zero.

Incorporating the transportation cost term (2) into the main specification (1) yield our baseline specification:

$$
\begin{aligned}
\operatorname{In}\left(\text { Trade }_{i j}+1\right) & =b_{0}+b_{1} \ln \left(Y_{i}\right)+b_{2} \ln \left(X_{j}\right)+b_{3} \text { Tariff }_{i j} \\
& +b_{4,1} \ln \left(\text { Rail }_{i j}\right)+b_{4,2} \ln \left(\text { AirC }_{i j}\right) \\
& +b_{4,3} \ln \left(\text { OceanC }_{i j}\right)+b_{5} \text { controls }_{i j}+e_{i j}
\end{aligned}
$$


One of the key assumptions in equation (3) is that bilateral cost only affects bilateral trade between the two corresponding countries. However, as stated at the start of the section, recent gravity model theory has shown the importance of the multilateral resistance effect of trade costs, that is, a reduction in bilateral transportation cost can have spillover effects for a third country. For example, lower transportation costs between China and Europe might not only boost international trade in the Eurasian region, but also substitute Eurasia's trade with the US. To capture the multilateral resistance effect, Anderson and Wincoop (2003) and Head and Mayer [2014] propose a more structural specification of the model. But the nonlinear calculation involved sometimes has difficulty in the convergence and sensitivity of the initial parameter choice. Baier and Bergstrand (2009) suggested a linear approximation (by means of a first order Taylor series expansion) of the multilateral resistance terms to avoid the non-linear procedure used in the traditional structural gravity model. Following this approach, we rewrite the trade cost term as:

$$
Z_{i j}^{\prime}=\ln Z_{i j}-\left(\stackrel{\circ}{j}_{j} q_{j} \ln Z_{i j}+\underset{i}{\stackrel{\circ}{a}} q_{i} \ln Z_{i j}-\stackrel{\bigcirc}{a}_{i}^{\circ} q_{j} q_{j} \ln Z_{i j}\right)
$$

In theory $\vartheta_{i}$ and $\vartheta_{j}$ denotes the GDP share of country $i$ and country $j$, but in the regression we follow Baier and Bergstand(2009)'s suggestion and define them as the average share to avoid endogeneity problem. $X_{i j}$ represents the trade cost variable, i.e. tariff and transportation costs.

Now, we can extend equation (3) to the following baseline specification of the paper,

$$
\begin{aligned}
\ln \left(\text { Trade }_{i j}+1\right) & =b_{0}+b_{1} \ln \left(Y_{i}\right)+b_{2} \ln \left(X_{j}\right)+b_{3} \text { Tariff }^{\prime} \\
& +b_{4,1} \ln \left(\text { Rail }^{\prime}{ }^{\prime}{ }_{i j}\right)+b_{4,2} i \ln \left(\text { AirC }^{\prime}{ }_{i j}\right) \\
& +b_{4,3} \ln \left(\text { OceanC }^{\prime}{ }_{i j}^{\prime}\right)+b_{5} \text { controls }_{i j}+e_{i j}
\end{aligned}
$$

Where the variables with "'” are defined as in equation (4). Following Baier and Bergstrand (2009), we restrict the coefficients before direct and spill over effects to have identical but oppositelysigned values.

The main interest of the paper is $b_{4,1}$ to $b_{4,3}$, which denotes the net effect of transportation cost on international trade. To grasp the economic magnitude of the effects of transportation we also need to compare the two coefficients with $b_{3}$, interpreting them as the equivalent reductions in tariffs. The model is estimated using the (Pseudo) Poisson Maximum Likelihood estimator. Using the PPML method has particular advantage of dealing with the zero trade issues, and has been shown by Silva and Tenreyro (2006) as a robust estimator in the presence of heteroscedasticity. 


\section{Appendix 4: Estimation results}

In this section, we report the detailed results for our estimation (Table A4.1). These results show that a reduction in transportation costs has a statistically significant and positive impact on international trade. First, in the case without considering the multilateral resistance term, we find that a 10 percent reduction in railway, air and maritime costs, increases trade by 2 percent, 5 percent and 1 percent respectively. As a second exercise, we take into account interrelationships between countries by estimating the multilateral resistance term previously described in equation (1). The results are similar both qualitatively and quantitatively (in column 3 and 4 , with and without control variables respectively $]^{12}$. All in all, a one percentage reduction in airline cost has the greatest impact on international trade. A one percentage reduction in railway cost has less than half that impact and a similar reduction in maritime one less than one fourth.

As regards the rest of the variables in Equation 1, the coefficient for the GDP is estimated to be between 0.7 and 0.9 , a bit smaller but still close to the theoretical prediction of one. In the same line, consistent with the existing literature, contiguity, common currency and common legal origins have a very large and positive effect on international trade. However, we do not find a statistically significant relationship between post-colonial linkages and international trade.

Table A4.1: Regression results

\begin{tabular}{|c|c|c|c|c|}
\hline $\begin{array}{c}\text { Method } \\
\text { VARIABLES }\end{array}$ & $\begin{array}{c}\text { (1) PPML_Bilateral } \\
\text { Export }\end{array}$ & $\begin{array}{l}\text { (2) PPML_Bilateral } \\
\text { Export }\end{array}$ & $\begin{array}{l}\text { (3) PPML_Multilateral } \\
\text { Export }\end{array}$ & $\begin{array}{l}\text { (4) PPML_Multilateral } \\
\text { Export }\end{array}$ \\
\hline \multirow[t]{2}{*}{ Bilateral tariff } & $-0.098^{* *}$ & $-0.032^{* *}$ & $-0.132^{* *}$ & $-0.103^{* *}$ \\
\hline & [4.52] & [3.94] & {$[4.50]$} & {$[8.26]$} \\
\hline \multirow[t]{2}{*}{ Ln Railway } & $-0.157^{* *}$ & $-0.197^{* *}$ & $-0.221^{* *}$ & $-0.203^{* *}$ \\
\hline & (6.11) & (7.47) & $(2.74)$ & {$[8.51]$} \\
\hline \multirow[t]{2}{*}{ Ln Airplane } & $-0.820 * *$ & $-0.482^{* *}$ & $-0.790^{* *}$ & $-0.548^{* *}$ \\
\hline & (7.50) & (5.27) & (5.47) & [5.62] \\
\hline \multirow[t]{2}{*}{ Ln Maritime } & $-0.314^{* *}$ & $-0.122^{*}$ & $-0.327^{* *}$ & $-0.112^{* *}$ \\
\hline & [4.74] & (2.08) & [4.51] & (2.87) \\
\hline \multirow[t]{2}{*}{ Contiguity } & & -0.016 & & 0.029 \\
\hline & & (0.10) & & (0.22) \\
\hline \multirow[t]{2}{*}{ Common currency } & & $1.992^{* *}$ & & $1.993^{* *}$ \\
\hline & & (6.71) & & (16.61) \\
\hline \multirow[t]{2}{*}{ Common legal origin } & & $1.040^{* *}$ & & $0.824^{* *}$ \\
\hline & & $(8.90)$ & & [9.75] \\
\hline \multirow[t]{2}{*}{ Colonial link } & & -0.303 & & -0.114 \\
\hline & & (1.79) & & (0.68) \\
\hline \multirow[t]{2}{*}{ GDP i } & $0.936^{* *}$ & $0.799 * *$ & $0.807^{* *}$ & $0.775^{* *}$ \\
\hline & (30.47) & [26.91] & (15.77) & (50.07) \\
\hline \multirow[t]{2}{*}{ GDP $n$} & $0.864^{* *}$ & $0.740^{* *}$ & $0.813^{* *}$ & $0.727^{* *}$ \\
\hline & (30.46) & [24.38] & (17.45) & (35.13) \\
\hline
\end{tabular}

\footnotetext{
${ }^{12}$ This finding is consistent with Head and Mayer (2014) whose simulations indicate that the Modular Trade Impact including the multilateral resistance is close to the Partial Trade Impact excluding the multilateral resistance term.
} 


\begin{tabular}{ccccc} 
Constant & $-5.905^{* *}$ & $-7.839^{* *}$ & $4.395^{* *}$ & $-7.689^{* *}$ \\
& {$[7.75)$} & $(12.79)$ & $(4.73)$ & $(4.84)$ \\
$\mathrm{R}^{2}$ & 0.89 & 0.97 & 0.89 & 0.96 \\
Observations & 12,819 & 12,819 & 12,819 & 12,819 \\
\hline
\end{tabular}

Robust standard errors in parentheses

${ }^{* * *} p<0.01,{ }^{* *} p<0.05,{ }^{*} p<0.1$

References

Anderson J. E. and E. Van Wincoop (2003) 'Gravity with Gravitas: A solution to the Border Puzzle', American Economic Review 93(1): 170-192

Baier, S. L. and J. H. Bergstrand (2009) 'Bonus vetus OLS: A Simple Method for Approximating International Trade-cost Effects Using the Gravity Equation', Journal of International Economics ??(1), $77-85$

DB Schenker (2012) 'Rail based transports between China and Europe', available at http://www.iccwbo.org/Data/Documents/Transport-and-logistics/6-Rail-based-transports-betweenChina-and-Europe/

Simeon Djankov, S., C. S. Hendrix, R. Z. Lawrence, S. Miner, E. M. Truman and F. Toohey [2016) 'China's Belt and Road Initiative: Motives, Scope and Challenges', PIIE Briefing 16-2, Peterson Institute for International Economics, available at https://piie.com/publications/piie-briefings/chinas-belt-androad-initiative-motives-scope-and-challenges

Garcia-Herrero, Alicia (2015) 'China pushing "build now, pay later" model to emerging world', Nikkei Asian Review, available at http://asia.nikkei.com/Viewpoints/Perspectives/China-pushing-build-now-pay-later-model-toemerging-world?page $=1$

Head, K. and T. Mayer [2014] 'Gravity Equations: Workhorse,Toolkit, and Cookbook', in Gopinath, G., E. Helpman and K. Rogoff (eds) Handbook of International Economics, volume 4: 131--195, Elsevier

Silva J. S. and S. Tenreyro (2006) 'The log of gravity', The Review of Economics and Statistics 88(4): 641-658, Elsevier

United Nations (1999) Development of the trans-Asian railway, UN Economic and Social Commission for Asia and the Pacific, available at http://www.unescap.org/sites/default/files/tarscfulltext 1980.pdf 
(c) Bruegel 2016. All rights reserved. Short sections, not to exceed two paragraphs, may be quoted in the original language without explicit permission provided that the source is acknowledged. Opinions expressed in this publication are those of the author[s] alone.

Bruegel, Rue de la Charité 33, B-1210 Brussels

(+32) 22274210

info@bruegel.org

www.bruegel.org 